\title{
Karl Marx, dialéctica material de la historia
}

\section{JAIME RICARDO REYES CALDERÓN*}

Recibido: 1 de agosto de 2018 - Evaluado: 29 de octubre de 2019 - Aceptado: 5 de diciembre de 2019

Citar como: Reyes Calderón, J. R. (2020). Karl Marx, dialéctica material de la historia. Hallazgos, 17(33), 163-196. Dor: https://doi.org/10.15332/2422409X.4460

* Doctor en Educación. Coordinador académico de la Institución Educativa Santo Ángel de Cúcuta y miembro de número de la junta directiva de la Academia de Historia de Norte de Santander, Colombia.

Correo electrónico: keraj1964@hotmail.com

ORCID: https://orcid.org/0000-0002-3560-5873 


\section{Resumen}

En este artículo de reflexión se hace un acercamiento a lo que se podría denominar la ciencia histórica en el marco amplio de una posible teoría del conocimiento revolucionario en la dialéctica materialista de Marx. Se recuerda en un primer momento el tema de la dialéctica en el idealismo hegeliano como supuesto necesario de abordar para estudiar a Marx. Se pasa a considerar la distinción entre materialismo dialéctico y materialismo histórico. Articulada a esta distinción, se sigue con el gran eje epistemológico marxista, la unidad entre teoría y praxis y entre ciencia y revolución. Tras esta precisión se esboza una recuperación de Marx con un balance del aporte marxista al conocimiento científico social.

Palabras clave: ciencia, dialéctica, Hegel, Marx, materialismo histórico, praxis, teoría.

\section{Karl Marx, material dialectic of history}

\section{Abstract}

In this reflection article an approach is made to what could be called historical science in the broad framework of a possible theory of revolutionary knowledge in Marx's materialist dialectic. At the start, the theme of the dialectic in Hegelian idealism is remembered as the necessary supposition to study Marx. Subsequently, the distinction between dialectical materialism and historical materialism is considered. Coupled with this distinction, it continues with the great Marxist epistemological axis, the unity between theory and praxis and between science and revolution. Following this precision, a recovery of Marx is outlined with a balance of the Marxist contribution to social scientific knowledge.

Keywords: science, dialectic, Hegel, Marx, historical materialism, praxis, theory.

\section{Karl Marx, dialética material da história}

\section{Resumo}

Neste artigo de reflexão se faz uma aproximação ao que poderia se denominar a ciência histórica no marco amplo de uma possível teoria do conhecimento revolucionário na dialética materialista do Marx. Lembra-se em um primeiro momento o tema da dialética no idealismo hegeliano como suposto necessário de abordar para estudar ao Marx. Passa-se a considerar a distinção entre materialismo dialético e materialismo histórico. Articulada a esta distinção, continua-se com o grande eixo epistemológico marxista, a unidade entre teoria e práxis e entre ciência e revolução. Após esta precisão esboça-se uma recuperação do Marx com um balanço do aporte marxista ao conhecimento científico social,

Palavras-chave: ciência, dialética, Hegel, Marx, materialismo histórico, práxis, teoria. 


\section{Introducción}

En la mitad del siglo xıx, la historia romántica determinada por los criterios idealistas de Hegel y sus seguidores cercanos determinaron un horizonte de comprensión por el cual la historia se fundaba en las hazañas de prohombres cuya integridad y excelencia constituyeron el fermento para el nacimiento de las naciones. Tras la experiencia positivista que muy severamente cuestionaba sobre la firmeza de las narraciones históricas, vino un movimiento que examinó las factualidades sociales desde el punto de vista del entramado económico-político, que insistía en la urgencia de un cambio revolucionario. El método dialéctico que aspiraba a dar cuenta racional de la totalidad de lo real recibe una nueva orientación en Marx, quien se alejará progresivamente del grupo conocido como los jóvenes hegelianos. Nació así el materialismo histórico como la interpretación de la dialéctica de la historia desde los fundamentos de las relaciones productivas descubiertos a través de una crítica de la economía política del capitalismo.

En el marco de los doscientos años del natalicio de Marx, se señalan algunas constantes interpretativas del modelo de ciencia histórica derivado de su obra. Este artículo de reflexión quiere ofrecer una presentación panorámica de los puntos básicos de una posible teoría revolucionaria del conocimiento en Marx, fundada en la comprensión dialéctica material de la historia. Para tal fin, nos desplazaremos desde el origen hegeliano hasta algunos criterios de la ciencia formulada por Marx, y así concluir con un bosquejo de la vigencia de su pensamiento, más allá de las posibles malinterpretaciones y los reduccionismos que el pensamiento marxista ha sufrido en estos dos últimos siglos.

\section{La dialéctica en Hegel}

La dialéctica tiene su historia y no se puede negar la raigambre hegeliana en Marx. En El capital, Marx (2008) reconoce: “Me declaré abiertamente, pues, discípulo de aquel gran pensador y llegué incluso a coquetear aquí y allá, en el capítulo acerca de la teoría del valor, con el modo de expresión que le es particular” (p. 20). Las condiciones de diálogo, análisis, discusión y creación del pensamiento en su época acercaron a Marx no tanto a la dimensión erudita y purísimamente abstracta de la dialéctica hegeliana, sino más bien al uso interpretativo y retórico de algunas categorías hegelianas. Pero ver los matices de la dialéctica marxista requiere del honesto examen de la hegeliana. 
Se asoma este estudio, primero, a la Fenomenología del Espíritu (Hegel, 2010[1807]). Hegel ofrece su sistema filosófico como un proyecto por el cual se superan las parcialidades enunciadas en las filosofías anteriores. Su discurso define la dialéctica no solo como instrumento, como argumentación, como método del filosofar, sino que también establece el carácter de lo real, del ser, de la constitución de la totalidad. La dialéctica es la esencia de la realidad. La dialéctica es el acontecer del concepto que se clarifica ascendiendo de entre lo borroso y lo parcial. En Hegel, la dialéctica es lo que es, es el Ser, significa lo primigenio y a lo que tiende todo lo demás, que forma parte de sí mismo. En ese planteamiento que progresa respecto a las meras filosofías del entendimiento, se quiere afirmar a la filosofía especulativa, al saber razonador, como formación de la totalidad. Para Hegel (2010[1807]), es método entendido como mostración del Espíritu, como ejercicio de autoconocimiento de la esencialidad de la totalidad, como la lógica:

La filosofía, en cambio, no considera una determinación inesencial, sino que la considera en la medida en que es esencial; su elemento y contenido no son lo abstracto o inefectivo, sino lo efectivamente real, lo que se pone a sí mismo y vive en sí, la existencia en su concepto [...] El método no es otra cosa que la construcción del todo erigida en su esencialidad pura. (p. 107) ${ }^{1}$

La Fenomenología del Espíritu (2010[1807]) quiere exponer la experiencia de la conciencia que se eleva hasta ser saber absoluto. Esta percepción experiencial remite primeramente a una consideración de la dialéctica como la esencia vital de la realidad. La dialéctica, antes que ser un ordenamiento conceptual lejano de las situaciones corrientes del existir, es el alma de la realidad común y corriente. El todo vital se manifiesta dialécticamente. La vida es expresión de la dialéctica. Hegel (2010[1807]), mostrando la inmediatez de la experiencia dialéctica, realiza una colorida descripción al inicio del prólogo de la Fenomenología:

El capullo desaparece con la floración, y podría decirse que queda así refutado por ella, del mismo modo que el fruto declara la flor como una existencia falsa de la planta, y brota como su verdad en lugar de aquélla. Estas formas no solo se diferencian entre sí, sino que, en tanto que incompatibles, se van desplazando unas a otras. A la vez, sin embargo, su naturaleza fluida hace de ellas momentos de una

1 Salvo cuando se indique lo contrario, el énfasis en palabras o frases en las citas textuales de este artículo es de los textos originales. 
unidad orgánica, en la que no solo no entran en disputa, sino que la una es tan necesaria como la otra, y únicamente esta misma necesidad es lo que llega a constituir la vida del todo. (p. 57)

En el extremo final del recorrido de la Fenomenología se presenta el gran agente de la dialéctica. La conciencia se ha desplegado en sus múltiples figuras y ha conseguido afirmarse como totalidad. La historia de la cultura procurada por el conjunto de toda actividad solo es aprehensible en su comprensión dialéctica, en su acepción de Espíritu. Lo real es Espíritu, es Absoluto, se autotrasparenta a sí mismo, es un sujeto autoconsciente que disuelve las oposiciones. Absoluto que identifica sujeto-objeto, finito e infinito, materia y concepto. La dialéctica es el movimiento negativo de la realidad (Espíritu) que se afirma, niega y recupera en un esquema de afirmación, contradicción y conciliación. Vattimo (2012) defiende a Hegel, a propósito del fenomenismo de corte empirista o kantiano: “Con Hegel más bien observamos ya una forma de corregir esta pretensión: con la teoría del espíritu como instancia histórica suprapersonal, y del saber en su totalidad como efectivo sujeto histórico” (p. 58).

Hegel (2010[1807]) señala que la realidad es el Espíritu, quien a su vez es, en la medida en que él mismo se ha propuesto y reconocido en las figuras de la historia, deviniendo como la figura de la totalidad, como el centro vital, la vida verdadera del movimiento. Así pues, la dialéctica es Espíritu, es la realidad que se ha movido en la actividad universal. El Espíritu es:

Substancia y esencia universal permanente, igual a sí misma: él, el espíritu, es el fundamento y punto de partida, no quebrantado ni disuelto de la actividad de todos, así como su fin y meta en cuanto lo en-sí pensado de toda autoconciencia. Esta substancia es, asimismo, la obra universal que se engendra por la actividad de todos y cada uno como la unidad e igualdad de ellos, pues ella es el ser-parasí, el sí-mismo, la actividad. [...] El espíritu es por consiguiente, la esencia real y absoluta que se sustenta a sí misma. Todas las figuras anteriores de la conciencia son abstracciones suyas; son esto: que él se analice distinga sus momentos, y se demore en algunos singulares de entre ellos. Este aislar tales momentos presupone al espíritu. Y subsiste por él o en otros términos, existe solamente en su seno, pues él es la existencia. (p. 523)

La presencia de la dialéctica es totalizante. Lo real, lo existente, es dialéctico. Progresa dialécticamente cada nivel del ser, cada espacio del existir. La naturaleza material es dialéctica igual que la historia humana, la filosofía, el arte, la divinidad 
y el Estado. La dialéctica es el camino por el cual se desarrolla todo: no permite exclusión alguna de términos, fenómenos o situaciones; uniformiza lo aparentemente inconexo. La dialéctica es el lenguaje de comprensión que sirve a la totalidad. Esto se patentiza en toda la obra escrita de Hegel, quien desarrolla sus argumentaciones proponiendo el discurso a través de las estructuras triádicas.

En la Enciclopedia de las Ciencias Filosóficas (2005[1830]) Hegel ofrece un modelo de su conocido esquema triádico de consideración de lo dialéctico. Valga recordar que el léxico de "tesis-antítesis y síntesis” pertenecía a Fichte, con quien Hegel, se cree, no quería quedar debiendo nada. Por tal razón, apela a describir la dialéctica como "lados", como "momentos", determinando el ser como la lógica: "Lo lógico, según la forma, tiene tres lados: $\alpha$ ) el abstracto o propio del entendimiento; $\beta$ ) el dialéctico o racional-negativo; $\gamma$ ) el especulativo o racional positivo” (p. 182).

Hegel conoce el recorrido del método dialéctico a lo largo de la historia de la filosofía. Ha juzgado a Kant como emblema de una filosofía del entendimiento que poco ha sugerido de crítica y de genialidad para la marcha de la filosofía, dado que ha acentuado los dualismos y las fragmentaciones de la realidad, negando la vida de las ideas. La investigación y exposición del sistema exige un método acorde con las pretensiones de totalidad, autonomía, vitalidad, interioridad y progreso de la filosofía del Espíritu. "El método no es forma extrínseca, sino el alma y el concepto del contenido, del cual la forma solo se distingue en tanto los momentos del concepto" (Hegel, 2005[1830], p. 298).

Entonces, la exposición de la vida del Espíritu que se ha elevado hasta ser saber absoluto ha sido agenciada por la filosofía especulativa que en Hegel cuenta, como garante de veracidad, con la dialéctica considerada como método. La dialéctica es el Espíritu y es la manera como se comporta para reconocerse. El primer momento de la tríada, momento del ser o lo inmediato, afirmación abstracta, lo superable inicial, arranca con lo criticado a Kant, es decir, con lo propio del entendimiento, con lo que no tiene definición, elaboración y, por ello, carente de concreción; Hegel lo censura como simplemente "abstracto", en oposición a lo real, a lo firme, a lo concreto. Nos afirma Hegel (2005[1830]) que:

Los momentos del método especulativo son: $\alpha$ ) el comienzo que es el ser o lo inmediato [...] aparece como afirmación abstracta [...] el ser es el concepto aún no sentado como concepto o el concepto en sí. Por consiguiente, en cuanto concepto aún indeterminado, esto es, concepto meramente en sí o determinado inmediatamente, este ser es igualmente lo universal. (p. 296) 
Pasamos al segundo momento, el propiamente dialéctico o racional-negativo. La inmediatez del primer momento caracteriza las afirmaciones de las filosofías del entendimiento para las cuales hay un referente de verdad que no admite oposición ni movimiento, sino que simplemente niega lo opuesto como una contradicción a lo verdadero que debe ser desecho por inapropiado. Las determinaciones allí no admiten controversia. Pero lo dialéctico exige la consideración de lo opuesto, lo contradictorio, la negación de lo inicialmente propuesto, como parte no del error sino del movimiento, del alma, del ser de la realidad, del pensamiento de la realidad, que solo es en la medida del no-ser. El primer momento es la afirmación del concepto "impropio", admitido en su parcialidad, en su espontánea naturalidad finita. El momento dialéctico es un momento crítico porque advierte y desvela la parcialidad, la limitez, la falibilidad óntico y lógica de esa primera afirmación pretendidamente afirmativa, clara y racional.

En la Ciencia de la lógica Hegel (1812/2011) dedicará un buen espacio para reflexionar óntico-lógicamente sobre la unidad del ser y de la nada (capítulo primero, la dialéctica expresada ónticamente en Ser-Nada y Devenir). Bajo el concepto hegeliano de la unidad absoluta del ser, unidad de lo finito en lo infinito, que también es, por la consabida unidad entre ser y pensar, unidad de lo afirmado y lo negado, entre representaciones y conceptos, entre filosofías y filosofía racional, entre entendimientos y razón. "Lo que es racional es real, y lo que es real es racional”, sentencia en la Filosofía del derecho (Hegel, 2000[1821], p. 74). Aunque nos adelantamos al tercer momento, Hegel considera que lo contradictorio no es externo ni al ser, ni a la reflexión del ser, ni a la comprensión racional conceptual de este. No hay determinaciones excluyentes ni separatidades, solo momentos contradictorios que pertenecen a esa misma unidad que se mueve. El segundo momento aporta necesariamente la negación del primero, una superación de lo finito y lo meramente del entendimiento, que surge de sí mismo, como correspondencia a su esencialidad, a su movimiento intrínseco.

Continuamos con el recorrido en la Enciclopedia de las Ciencias Filosóficas. Lo dialéctico es movimiento, es la mutación, la transposición, el devenir que supera lo afirmado en una contradicción que surge del sí mismo. Habituados a la dialéctica de las luchas verbales que conquistan audiencia y aplauso, o vista la dialéctica como mera técnica de exposición discursiva en disputas teóricas o como uso impropio que es mera lógica de lo aparente, Hegel recompone la tradición y reconoce una dialéctica de la totalidad, identificando el segundo momento como superación y acción esencial del proceder científico, reflexión de las manifestaciones del Espíritu como Absoluto, derivación jalonada por impulsos del progreso. Hegel (2005[1830]) así lo expresa: 
ß) El momento dialéctico es el propio superar de tales determinaciones finitas y su pasar a sus opuestas [...] La dialéctica, por el contrario, es este rebasar inmanente en el cual se expone la unilateralidad y limitación de las determinaciones del entendimiento tal como es, a saber, como su propia negación. Todo lo finito es este superarse a sí mismo. Por ello, lo dialéctico constituye el alma móvil del proceder científico hacia adelante y es el único principio que confiere conexión inmanente y necesidad al contenido de la ciencia, del mismo modo que en él reside en general la verdadera y no extrínseca elevación sobre lo finito. (pp. 183-184)

Llegamos al tercer momento, el momento especulativo o positivamente racional. Las contradicciones generadas son resueltas y superadas, logrando un nuevo nivel de ser y de razón. Eso aparentemente contradictorio está contenido en la integralidad de la nueva afirmación. De un inicio abstracto, porque consistía en la mera afirmación de lo diferente, de lo diferenciado, luego de considerar las negaciones, llegamos a un final conceptual, pero concreto, dado que la razón superó parcialidades, límites y contraposiciones irrelevantes, al ser considerado todo el movimiento como una transformación hasta la novedad. El resultado final no se encasilla en unas cuantas determinaciones, pues lo particular y parcial se ha superado, ya su afirmación concatena las diferencias, da razón de la totalidad, reclama la presencia de lo infinito. De esta manera, lo dialéctico tiene un comportamiento circular, pues esta nueva afirmación será el punto de arranque para nuevas superaciones, nuevos ascensos, más importantes y universales comprensiones. Demos a Hegel (2005[1830]) la manifestación de este cierre dinámico en sus elocuentes palabras:

ү) Lo especulativo o racional-positivo aprehende la unidad de las determinaciones en su oposición, lo afirmativo que se contiene en la disolución de ellas y en su pasar. 1) La dialéctica tiene un resultado positivo porque tiene un contenido determinado o [lo que es lo mismo], porque su resultado no es verdaderamente la nada abstractay vacía, sino la negación de determinaciones [sabidas como] ciertas, las cuales se conservan en el resultado, precisamente porque éste no es una nada inmediata, sino un resultado. 2) Este [resultado] racional, por consiguiente, aunque sea algo pensado e incluso abstracto, es a la vez algo concreto porque no es una unidad simple, formal, sino unidad de determinaciones distintas. Con meras abstracciones o pensamientos formales la filosofía nada tiene que ver en absoluto, sino solamente con pensamientos concretos. 3) En la lógica especulativa se contiene la mera lógica del entendimiento [...] de esta manera [la lógica especulativa] se convierte en la lógica usual, una historia [o enumeración] de varias determinaciones del pensamiento colocadas juntas y que en su finitud valen como algo infinito. (p. 184) 
En contraposición con Kant, Hegel ofrece no solo una dialéctica que distingue y examina las ideas, sino una dialéctica que además de imprimir negatividad en las distinciones, integra lo presuntamente excluido. Dialéctica que asume cada franja del ser y el pensar, dialéctica que suprime distancias y busca formaciones más avanzadas. Dialéctica no es solo exclusión, es por el contrario reconocimiento de realidades superiores. Lo dialéctico es método, pero sobre todo es la vida propia de la totalidad, la forma de ser de la realidad que es unidad infinita y eterna de pensamiento y ser. Con esto podríamos decir que Hegel radicaliza el dinamismo crítico inaugurado por Kant, expandiendo su sentido por la comprensión del progreso, de la historia, del devenir intrínseco de la realidad. Así, Hegel extiende el idealismo trascendental kantiano a un Idealismo Absoluto, de alcances totalizadores e históricos, es decir, la Metafísica más ambiciosa y omniabarcante de la filosofía occidental. Cerremos esta aproximación con otra manera de formular el esquema triádico ("ser-en-sí”, “ser-para-sí” y “ser-en-sí-para-sí”), cercana a los derroteros de la Ciencia de la lógica, inscrita en la "Lógica menor", o primera parte de la Enciclopedia (2005[1830]), en referencia a lo eminentemente conceptual que termina coronándose en la Idea:

\footnotetext{
De este modo el concepto, partiendo de su ser-en-sí y concluyéndose consigo por la mediación de su diferencia y de la superación de ella, es el concepto realizado, esto es, el concepto que contiene el ser-puesto de sus determinaciones en su ser-para-sí: es [ahora] la idea, para la cual al mismo tiempo, en cuanto es lo absolutamente primero (en el método), este final es únicamente la desaparición de la apariencia de que el comienzo fuera algo inmediato y ella fuera un resultado: es conocer que la idea es la totalidad única. (p. 298)
}

\section{Marx, izquierda hegeliana e idealismo hegeliano}

El idealismo hegeliano fue, pues, la cuna filosófica desde la cual se tiene que delimitar el campo de la producción del conocimiento, la práctica científica, en Marx. "Marx y Engels eran ya dialécticos antes de ser materialistas" (Korsch, 1971, p. 41). El joven Marx entró en contacto —en los inicios del proceso de formación de su original pensamiento- con uno de los círculos de pensadores derivados de Hegel. El hegelianismo se desarrolló principalmente en dos vertientes, la derecha y la izquierda. El ala "derecha" se decantaría por aspectos de índole teológica. En la derecha hegeliana "se apresuraban a identificar (dialécticamente, eso sí: como unidad en la diferencia) a Dios con Jesucristo y al Estado con el Hombre (y con el Hombre por antonomasia: el 
Príncipe)” y la izquierda “enfatizaba el respecto lógico-histórico del dístico, sosteniendo que la identidad entre la razón y el mundo no era algo eterno y dado sin más, sino el resultado de un gigantesco proceso de depuración, de aniquilación y de renovación” (Duque, 1999, pp. 130-136).

La izquierda hegeliana se ramificó también. Un sector muy fuerte representado por Bruno Bauer, los “junghegelianer propiamente dichos”, quienes se distinguían por "una confianza casi ilimitada en el poder de la filosofía para cambiar el orden existente y establecer un mundo mejor" (Duque, 1999, p. 138). El gran aporte a la historia del pensamiento es que conformaron, por primera vez en la historia, un partido filosófico, ya que "lograron constituirse como verdaderos grupos, formando células de lectura en común, de debate y de creación de periódicos y revistas” (p. 137).

Un segundo sector era el de "los sensualistas como Ludwig Feuerbach". Un tercer sector fue el de "los socialistas revolucionarios como Marx y Engels" (Duque, 1999, p. 137). Entre el primer sector y los dos siguientes existe una brecha determinada por la funcionalidad del concepto, pues mientras los jóvenes hegelianos seguían enalteciendo el concepto como mediación fundamental, los otros (sensualistas y revolucionarios) buscaban relaciones menos imprecisas y más práctico-políticas para realizar la transformación efectiva, colectiva y expedita de la realidad considerada en su enorme complejidad.

Los hegelianos de izquierda nunca pudieron acercarse a una cátedra universitaria. Su actividad intelectual se constriñó al no permitírseles ningún tipo de financiamiento originado en el ejercicio docente e investigativo. El camino de sus investigaciones se enrumbó por las sinuosas sendas del periodismo, imposible de recorrer con éxito cuando lo examinado críticamente va en contra del establecimiento. Las penurias económicas y los mil y un conflictos entre pensadores, marcarán el resto de sus vidas.

Dejando el movimiento cultural que fue matriz de comprensión del hegelianismo, pasamos a la confrontación con categorías de Hegel mismo. La ideología alemana (Marx, 1974) es la gran fuente marxista que nos permite matizar los acercamientos y las diferencias respecto de la filosofía alemana en general y, para nuestro propósito, de la hegeliana en particular. Para Marx, los hegelianos de izquierda se engañaban al separar indebidamente realidad material y producciones espirituales, pues "las representaciones, los pensamientos, los conceptos y, en general, los productos de la conciencia por ellos independizada eran considerados como las verdaderas ataduras del hombre” (Marx, 1974, p. 18). Así, entonces, Marx llevó su exploración más allá de las disputas metafísicas a las que se entregaban los filósofos alemanes, los viejos 
hegelianos y los nuevos, quienes en fértil creatividad verbal combinaron y recompusieron las categorías hegelianas sin conseguir nada más que darle un terrible fin al idealismo hegeliano. Sin preguntarse jamás por la realidad que sustentaba esas producciones de conciencia: "A ninguno de estos filósofos se le ha ocurrido siquiera preguntar por el entronque de la filosofía alemana con la realidad de Alemania" (Marx, 1974, p. 18). Con el sarcasmo que se le reconoce, Marx (1974) calificará así tal movimiento filosófico alemán:

Trátese, en verdad, de un acontecimiento interesante: del proceso de putrefacción del Espíritu absoluto. Al apagarse la última chispa de vida, entraron en descomposición las diversas partes integrantes de este caput mortuum, dieron paso a nuevas combinaciones y se formaron nuevas sustancias. (p. 15)

Para Marx, el idealismo enunciaría un absurdo al definir que las condiciones materiales (la producción, la manera como se relacionan patrono y obrero, la explotación por medio del trabajo, el hambre de los suburbios) son consecuencia de la Idea (el Espíritu Absoluto) que, omnipotente, provee la realidad. Marx señalaría entonces que los frutos de la cabeza (pensamientos, conceptos, representaciones) han acabado por imponerse a su cabeza (lo fáctico, lo existencial). La comprensión idealista termina siendo un discurso sobre lo racional de las conductas íntimas que por sumatorias abstractas se configuran en una visión del ser, de la sociedad y del Estado como expresiones del Espíritu. Estas proposiciones "revolucionarias" constituirían mera ideología, es decir, reproducción falsa de la realidad, justificación racional de la opresión fundamental. Marx (1974) afirma:

Hasta ahora, los hombres se han formado siempre ideas falsas acerca de sí mismos, acerca de lo que son o pudieran ser. Han ajustado sus relaciones a sus ideas acerca de Dios, del hombre normal, etc. Los frutos de su cabeza han acabado por imponerse a su cabeza. Ellos, los creadores, se han hundido ante sus creaturas. (p. 11)

En Marx, la conciencia o las formas de la conciencia (representación, pensamientos, educación, lenguajes, leyes, moral, política, religión, estado, filosofía) constituyen superestructuras, un plano segundo y externo de lo auténticamente real, no tienen independencia ni existencial ni conceptual, son producciones de una realidad material no explorada ni entendida. Así propone Marx (1974):

Las representaciones, los pensamientos, el comercio espiritual de los hombres se presentan todavía, aquí, como emanación directa de su comportamiento material. Y lo mismo ocurre con la producción espiritual [...] Los hombres son los 
productores de sus representaciones, de sus ideas, etc., pero los hombres reales y actuantes tal y como se hallan condicionados por un determinado desarrollo de fuerzas productivas. (pp. 25-26)

La base material de la sociedad es el fundamento de las producciones reflexivas. La conciencia forjada principalmente en las relaciones productivas representa la consecuencia espiritual del trasegar económico-productivo. Desde la praxis económica se establecen unas correlaciones ideológicas, se realiza una reproducción espiritual de la realidad. "Los fenómenos y las formas fenoménicas de las cosas se reproducen espontáneamente en el pensamiento cotidiano como realidad. [...] El pensamiento común es la forma ideológica del obrar humano de cada día” (Kosík, 1984, pp. 31-32). En el trajinar de lo corriente de cada día surge una forma de comprensión de las cosas que aparenta ser la realidad y la verdad. La realidad debe ser estudiada mediante un rodeo, un esfuerzo, un trabajo cuya producción se ocupa de desentrañar las causas mismas de lo real, y no simplemente asumir como rotundo y definitivo lo que es apariencia y sentido común.

El pensar común concebido y multiplicado infinidad de veces en lo cotidiano se torna ideología. Las formas de pensamiento fragmentadas, fracturadas, independientes de los múltiples y complejos procesos productivo-sociales, esas comprensiones superficiales y limitadas del pensamiento común, aparentan sustantividad, esencialidad en ellas mismas, pero son reflejos falseados de lo real. Las formas ideológicas son fundamentalmente una escisión de la realidad que invierte las realizaciones de la conciencia, que encubre los nexos entre lo aparente y lo auténticamente causal, que procura la separación entre práctica y reflejos teóricos y conceptuales. En La ideología alemana (Marx, 1974) informa:

La moral, la religión, la metafísica y cualquier otra ideología y las formas de conciencia que a ellas corresponden pierden, así, la apariencia de su propia sustantividad. No tienen su propia historia ni su propio desarrollo, sino que los hombres que desarrollan su producción material y su trato material cambian también, al cambiar esta realidad, su pensamiento y los productos de su pensamiento. No es la conciencia la que determina la vida, sino la vida la que determina la conciencia. (p. 26)

Lo auténticamente sustantivo, el fundamento por el cual es posible acceder a la comprensión de lo real, tal base, es la conjunción causal entre vida material y reproducción espiritual, es el substrato productivo, es el tejido de relaciones sociales que surgen como expresiones de las relaciones productivas, a las cuales se corresponden 
relaciones de pensamiento. La intelección de la realidad exige adentrarse en la estructura interna productiva condicionada por los caracteres histórico-sociales de cada formación humana particular. Damos paso al esfuerzo de pensamiento que persigue este objetivo, por lo demás realmente revolucionario.

\section{Materialismo dialéctico y materialismo histórico}

Resulta difícil proponer un horizonte claro y perfectamente perfilado de las concepciones marxistas, dado el continuo movimiento de investigaciones, polémicas, publicaciones, reinterpretaciones y nuevas producciones que fueron sucediéndose a lo largo de la vida del alemán, primero, y con la institución de la nación comunista después de la Revolución de Octubre. Súmese a esto la complejidad extraordinaria que significó establecer desarrollos de pensamiento a partir de directrices oficiales de Estados reconocidos como comunistas, gracias a su inspiración en Marx. Marx se formó como filósofo, debatió con los neohegelianos y optó por investigar con un interés político acerca de los fundamentos de una ciencia social, la historia material surgida de la crítica de la economía política del capitalismo. Es claro que no se propuso simplemente una respuesta a la filosofía alemana de su tiempo, sino un desarrollo crítico del basamento económico-político del capitalismo que denominó el materialismo histórico. También es claro que no presentó un desarrollo pormenorizado, de talante filosófico, de su propia versión de la dialéctica. Pacheco (1983) expresa:

Las concepciones y problemas de interpretación que genera el Materialismo Histórico [...] principalmente en aquello que involucra una concepción de "filosofía de la historia”, representado también por el materialismo dialéctico, ofrece una primera dificultad al no encontrarse propiamente sistematizado en la obra de Marx. (p. 35)

El materialismo dialéctico, denominado por algunos como Diamat (Botero, 1996), podría considerarse una interpretación de Engels (mucho menos hábil en los fondos filosóficos de reflexión) para defender las argumentaciones marxistas de las descalificaciones reaccionarias de su tiempo. Efectuada la transformación de la crítica marxista en doctrina autoritaria soviética, constituiría el saber dogmático y oficial de algunos partidos comunistas, preocupados por controlar cualquier brote metafísico, religioso y burgués, de las mentes populares recién emancipadas. A propósito, Desanti (1975) señala: 
Esos textos poéticos pero aberrantes de la Dialéctica de la naturaleza en los que celebrando la eternidad de la materia en movimiento él propone en el ciclo eterno de nacimiento y muerte la perspectiva consoladora de una eterna y cíclica reproducción del espíritu pensante. (p. 81)

En esta acepción, la naturaleza es toda la realidad. Lo concreto, lo empírico, los datos de la experiencia evolucionan dialécticamente, ellos solos, sin necesidades de la intervención humana, sin requerir la interpelación de la teoría como formulación creativa e imperfecta de una conciencia. Las elaboraciones mentales, que aquí no podemos llamar “teoría”, pues la teoría avanza con el avance de la práctica, son las famosas Leyes de la dialéctica. Engels en el Anti-Düring enunciará como leyes generales del movimiento y evolución de la naturaleza: "ley de la transformación de la cantidad en cualidad, y viceversa, la de la contradicción en el desarrollo e interrelación, y la negación de la negación” (Engels, 2014). En estas leyes está implícita la concepción de que el cosmos posee una regularidad total y absoluta. El pensamiento humano solo tiene que aplicar las leyes y anticipar los resultados del movimiento natural. El hombre es considerado, no opuesto dialécticamente a la naturaleza, sino incluido dentro de ella, como una organización superior de la materia. Los campos del saber se reformulan adelgazándose su espesor categorial, comprensivo y crítico: la ciencia se ocupa de lo material al tiempo que se suprime la filosofía por ser ideología del capitalismo y la religión porque "Es el opio del pueblo" (Marx, 1968[1844], p. 7).

Esta dialéctica haría un cambio semántico del que se desprendería una consecuencia práctica. Sánchez, sintetizando las críticas de Korsch (1971) a las relaciones teóricas del marxismo soviético, enunciará: “La materia ocupa el lugar del Espíritu hegeliano y la dialéctica se transfiere unilateralmente al objeto” (p. 10). Tal como se plantea este tipo de dialéctica, el hombre no conoce ni construye socialmente la historia. La realidad es independiente y autónoma de él, evoluciona sola gracias a que la naturaleza tiene perfecta regularidad funcional. El hombre se revolucionaría cuando el espectro material cambiara por la sola fuerza de sus determinaciones económicas. La historia no es historia del hombre que interactúa en una compleja sociedad; aquí la historia se considera como historia de la materia, de las formas económicas simples y genéricas.

En este enfoque, la naturaleza se contrae casi al punto de ser mero contexto físico-material. Las ideas de los hombres surgen por fuera del espectro material para fungir como metas que atraigan a la realización por parte de los hombres. Hacer historia sería identificar los vaticinios de la acción social y dar el cambio de 
una forma simple y declarativa, hacia un telos evidente e incontrovertible. La sociedad se desenvolvería mecánicamente siguiendo la automaticidad de las leyes de la dialéctica. "La versión catequística redujo la historia a una necesaria sucesión de modos de producción, en donde fatalmente uno reemplazaría a otro, explicando la dinámica social a partir de la globalidad y no del conocimiento de la historia” (Vega, 2005, p. 7).

Con este substrato epistémico, el marxismo deformado por la política partidista bolchevique, lo que trajo fue una burocratización de la estructura social que también se proyectó en una mecanización positivista de la investigación y la realización científica. Se reemplazaron las creencias fideístas, se encumbró un ateísmo a ultranza, pero se reprodujo la matriz sacralizada y dogmática que antes se criticaba a la religión. Esta tendencia floreció y se fijó en el régimen estalinista. Así recuerdan los historiadores Cardozo y Pérez (1976) este enfoque:

Bajo el stalinismo, las obras de los fundadores (ciertas partes más que otras), con el agregado de las de Lenín y del mismo Stalin, pasaron a constituir una especie de Summa theológica situada por encima de toda crítica, y de las cuales se admitía una interpretación: la oficial. (p. 68)

Pero esta derivación pretendidamente marxista, asumida como pensamiento rector de elementos activos del poder, esta falacia historicista-teleológica ajena a Marx, ha sido destructiva y devastadora. Esta aplicación indebida ha desconocido no solo la facticidad del complejo mundo social y político, sino ante todo, el querer de la base, el soporte popular auténtico y debidamente considerado mediante reales participaciones en la toma de decisiones y en la revolución democrática.

Karl Korsch, representante del marxismo más radical y crítico, se enfrentó a los teóricos de los años veinte del siglo xx, ocupados afanosamente en la construcción de la nación comunista producida luego de la revolución de octubre y de la devastación de la Primera Guerra Mundial. Los movimientos políticos que asumieron el marxismo repensaron las relaciones entre marxismo y filosofía, entre realidad material y ejercicio popular del poder. Pero para Korsch, la crítica a la filosofía, citando las primeras enunciaciones de Marx en las Tesis sobre Feuerbach y el Manifiesto del Partido Comunista, se deformó y derivó en un cientificismo inadmisible, pues "entienden por supresión de la filosofía: la sustitución de ella por un sistema de ciencias positivas, abstractas y no dialécticas” (Korsch, 1971, p. 36).

Lo político devino en automatismo resultante de la maquinaria material de lo productivo. Se escinde entonces la realidad. Surge el comunismo por invasión, por 
propagandismo populista, por enajenación dictatorial de una corporación. Se enuncia el discurso que quiere forzar la revolución sin comprensión ni conciencia de la realidad material, que además en su omnipotencia antidemocrática desconoce y aleja la posibilidad de autodeterminación contenida en la soberanía popular, en el sujeto colectivo que es la clase proletaria como agente del cambio revolucionario. De ese planteamiento dualista, Habermas (2005) explicará:

Las consecuencias de la comprensión instrumental de una práctica que no habría consistido en otra cosa que en una realización de la teoría, han sido destructivas y aun devastadoras. [...] la intervención de los revolucionarios, iluminada e informada por la teoría, no tendría otra finalidad que la de consumar la teleología de la historia, mantenida en movimiento por las propias fuerzas productivas. Pues bien, este tipo de confianza articulada en términos de filosofía de la historia no encuentra ya apoyo alguno en la soberanía popular procedimentalizada. [...] La razón práctica se ha quedado sin sujeto. (pp. 614-615)

Las consecuencias históricas de este dispositivo político de interpretación se han podido determinar. La Rusia zarista pasó de un régimen feudal a un régimen socialista. La idea incontrovertible de una revolución comunista forzó lo pretendidamente tenido como motor: el desarrollo material de las fuerzas productivas. Rusia no era una potencia capitalista. Las industrias, el proletariado, los sistemas de comercio y ganancia basados en la multiplicación de mercancías eran algo imposible. Pero sucedió la primera revolución comunista de la historia. Al respecto, apunta Hobsbawm (1998):

Todo el mundo daba por sentado, salvo los espíritus románticos convencidos de que las prácticas colectivistas de las aldeas rusas conducían directamente a un futuro socialista, que la revolución rusa no podía ser, y no sería, socialista. No se daban las condiciones para una transformación de esas características en un país agrario marcado por la pobreza, la ignorancia y el atraso y donde el proletariado industrial, que Marx veía como el enterrador predestinado del capitalismo, solo era una minoría minúscula. (p. 65)

Marx se tiene que considerar un moderno heredero de la Ilustración, plenamente deudor del poder crítico y creador de la razón. Las transformaciones agenciadas por el espíritu ilustrado se apartan de las cerrazones ontológicas absolutistas, de nuevos imperialismos, de nuevas religiones, de nuevas ideologías tan estatizantes y devastadoras como las identificadas en el oscurantismo medieval. Por tal motivo, un intento por “ontologizar” o “dogmatizar” cualquier saber reñiría 
con los supuestos progresistas, abiertos, reestructurantes de sus argumentaciones revolucionarias. A este respecto, Jaramillo (1998) nos define que el Marx moderno:

Si bien fue un crítico de la ilustración, fue también su heredero: el pensamiento de Marx es un pensamiento abierto a la experiencia. Marx fue un pensador radical, no un dogmático. No existe en Marx, en ninguna parte de su obra, una invitación a cerrar dogmáticamente el pensamiento. (pp. 40-41)

¿Qué constituiría la dialéctica marxista? Marx propone los alcances de su método dialéctico en el posfacio o epílogo de la segunda edición de El capital (2008), texto canónico indispensable para definir el carácter que separa y a la vez identifica lo más propiamente marxista:

Mi método dialéctico no solo difiere del de Hegel, en cuanto a sus fundamentos, sino que es, su antítesis directa. Para Hegel, el proceso del pensar al que él convierte incluso, bajo el nombre de idea, en un sujeto autónomo, es el demiurgo de lo real; lo real no es más que su manifestación externa. Para mí, a la inversa, lo real no es sino lo material traspuesto y traducido en la mente humana. [...] La mistificación que sufre la dialéctica en manos de Hegel, en modo alguno obsta para que haya sido él quien, por primera vez, expuso de manera amplia y consciente las formas generales del movimiento de aquélla. En él la dialéctica está puesta al revés. Es necesario darla vuelta, para descubrir así el núcleo racional que se oculta bajo la envoltura mística. (pp. 19-20)

En Hegel el ser, lo existente, lo esencial, es la Idea, en su forma de sistema conceptual agenciado por el desenvolvimiento del Espíritu Absoluto como entidad que se autorreconoce en el traslado dialéctico a través de su progresiva historia conceptual. En la apreciación de Lowy (1998), esta dialéctica del Espíritu Absoluto aparentemente se fija en la inmediatez del centro productivo mundial representado en Europa: "Dialéctica hegeliana teleológica y cerrada, de tendencia eurocéntrica. El objetivo final, necesario e inevitable, legitima los "accidentes históricos" como momentos del progreso en cuanto espiral ascendente" (p. 2). Todo aquello que tiene presencia concreta, material y sensible es real, por cuanto es expresión del desenvolvimiento del espíritu. Lo concreto vuelto acontecimiento factual, hecho histórico, accidente espacio-temporal, es porque se pudo conceptualizar — un tanto a posteriori- en un orden de progresión que manifiesta el ascenso del Espíritu. La vida es vida del espíritu, y es el Espíritu el que determina el estatuto óntico y cognoscente a cada objeto y realidad, a cada acontecer, a cada fenómeno social. 
El primer cambio que manifiesta Marx, el primer “darle la vuelta”, el romper con la cerrazón conceptual, es fundamentalmente de cara al sujeto, que recupera su vitalidad y protagonismo. El sujeto no avanza dialécticamente porque enuncie mayores abstracciones o más intrincados procesos conceptuales. El sujeto material, humano, social, si progresa es porque ha revolucionado lo precedente, ha modificado y complejizado las relaciones productivas, siendo artífice, desde sus mismas limitantes epocales, de la historia que ha querido forjar.

El sujeto de la historia material son los hombres concretos en sus relaciones materiales. Marx propone un criterio anticipatorio de las acciones de los hombres reales que revolucionan. La comprensión de la historia y el cambio revolucionario es la libertad y no la simplísima enunciación explicativa de lo real. No podemos hablar de una historia atomizada, caótica, sin sustanciar ideas y valores de emancipación, sin mirar una aspiración de progreso real. En la versión de La ideología alemana (1974) inscrita en la Obras escogidas (1974), tomo I, tal carácter político y revolucionario impulsa a Marx a afirmar la liberación:

No se puede liberar a los hombres mientras no estén en condiciones de asegurarse plenamente comida, bebida, vivienda y ropa adecuada y en suficiente cantidad. La "liberación" es un acto histórico y no mental, y conducirán a ella las relaciones históricas, el estado de la industria, del comercio, de la agricultura. (p. 23)

Teniendo en cuenta el contexto romántico de la época, que entronizaba el individualismo burgués como paradigma de vida y libertad, en Marx la liberación del hombre real admite como prueba no la autonomía reservada a los propietarios de los medios de producción, sino la existencia vital concreta, codependiente, que nos lanza necesariamente a la dimensión social signada bajo los intereses de grupo y clase. El capitalismo reifica al hombre, reifica las relaciones intersubjetivas, vuelve el universo de lo social, el ámbito intersubjetivo, una acción instrumental, mecánica, en la que el ser individual se trastoca definiéndose como cosidad por encima de la humanidad. El sistema productivo engrandece las cosas elaboradas, trasmutando en cosa también al hombre. Se ha de dar vuelta a la comprensión idealista porque esa dialéctica pervierte los órdenes de una realidad concreta, atribuyendo a la humanidad esencialidades físico-biológicas reduccionistas, enalteciendo a la mercancía como un ser personal omnipotente, un pequeño dios por todos adorado en el circuito capitalista. Esta inversión definida por el modo de producción capitalista en su principio esencial, el fetichismo de la mercancía, Marx (2012) la presenta así en el primer capítulo de El capital: 
A los productores [...] las relaciones sociales entre sus trabajos privados se les aparecen como son, esto es, no como relaciones sociales inmediatas entre las personas mismas en sus trabajos, sino más bien como relaciones materiales entre las personas y relaciones sociales entre cosas. (p. 197)

Desde el punto de vista del conocimiento, Marx propuso, pues, que lo que se conoce tiene relación con los hombres concretos pertenecientes a clases sociales particulares en sus interacciones clasales de producción. Lo que se conoce es la historia. A partir de Hegel, Marx realiza una labor de depuración para beneficiarse del poder racional y transformante de la dialéctica. Esa dialéctica hegeliana "al revés" toma un nuevo fundamento: un conocimiento que encuentra su razón en la base material, productiva, que le permite expresarse en un momento específico de la historia. Es decir, lo que se conoce fundamentalmente es el cambio de las sociedades porque estas avanzan gracias a las contradicciones materiales que a su interior se generan, jalonadas por el criterio directriz de la liberación. Desde una consideración del marxismo como humanismo, se puede afirmar con Dunayevskaya (2004):

La dialéctica hegeliana fue el crisol donde el materialismo se transformó en filosofía histórico-universal de la libertad, así como el proletariado en cuanto "sujeto" de la emancipación del hombre, que pone fin a todas las sociedades de clase, transformó el desarrollo dialéctico de la prehistoria del hombre en el despertar de todas las potencialidades humanas dentro de un "movimiento absoluto del devenir". (p. 91)

En Marx la historia se conoce porque posee un movimiento dialéctico. La historia es historia de las luchas provocadas dentro de las sociedades. La dialéctica es dialéctica de la historia. La dialéctica es dialéctica de la interacción del hombre a través de los siglos. Hombre que se hace clase social dividido en los polos antagónicos de opresores y oprimidos. En el Manifiesto del partido comunista así declara Marx: "La historia de todas las sociedades hasta nuestros días es la historia de las luchas de clase" (Marx y Engels, 1974, p. 111).

El conocimiento de la sociedad es materialista porque se funda en la comprensión de la multifactorialidad económico-política que insufla las condiciones materiales de la producción; es histórico porque esas condiciones no son estáticas sino que avanzan dialécticamente por el intercambio entre el hombre — clase social-y la naturaleza —entorno productivo modificado por el hombre-, reproduciéndose además en sus formas de pensamiento. Hacer ciencia no es solamente realizar laboratorismos o discursividades. La ciencia es la acción que realiza la historia, el 
conocimiento es acontecimiento de transformación de la realidad en su unidad de humanidad y naturaleza. En una nota perteneciente al principio de La ideología alemana así señala:

Conocemos solo una ciencia, la ciencia de la historia. Se puede enfocar la historia desde dos ángulos, se puede dividirla en historia de la naturaleza e historia de los hombres. Sin embargo, las dos son inseparables: mientras existan los hombres, la historia de la naturaleza y la historia de los hombres se condicionan mutuamente. (Marx y Engels, 1974, p. 12)

El conocimiento establece las conexiones complejas y cambiantes entre una base económica y una superestructura a la que corresponden formas de la conciencia social. Los grandes cambios sociales, políticos, jurídicos, educativos, religiosos y morales han sucedido no en la especificidad de ellos mismos, sino agenciados por un cambio profundo, estructural y definitivo de sus fundamentos materiales, económico-productivos. Se busca establecer desde las contradicciones los procesos de cambio que la estructura y la superestructura están impulsando. En la Contribución a la crítica de la economía política Marx (1974) definirá:

En la producción social de la vida, los hombres contraen determinadas relaciones necesarias e independientes de su voluntad, relaciones de producción, que corresponden a una determinada fase de desarrollo de sus fuerzas productivas materiales [...] al cambiar la base económica, se revoluciona, más o menos rápidamente, toda la inmensa superestructura erigida sobre ella. (pp. 517-518)

La realidad externa, la asumida sensible y despreocupadamente por el individuo y la masa, tal nivel real y cotidiano, resulta engañador, falseante, dado que la conciencia no conecta de manera inmediata aquel estrato fenoménico con las causas profundas que lo generan y alimentan. En el devenir de las acciones práctico-utilitarias (en términos de Kosík), lo que sucede en la cotidianidad, lo real, acontece en una clara independencia del mundo fenoménico respecto a su centro esencial y causal. Recuperando palabras de Marx, el marxista checo Kosík (1984) anota:

En virtud de que la esencia - a diferencia de los fenómenos- no se manifiesta directamente, y por cuanto que el fundamento oculto de las cosas debe ser descubierto mediante una actividad especial, existen la ciencia y la filosofía. Si la apariencia fenoménica y la esencia de las cosas coincidieran totalmente, la ciencia y la filosofía serían superfluas. (p. 29) 
La historia no aparece inmediatamente a la vista de cualquier existente. Se requiere un rodeo, una aproximación ponderada, reflexiva y creativa. En Marx la dialéctica hegeliana encontró uso racional y opuesto al engaño ideológico, en la aplicación sobre los fundamentos del capital, en el fenómeno axial de la teoría del valor, al construir una ciencia que diera cuenta revolucionaria de la totalidad concreta. La ciencia es, entonces, la dialéctica. La filosofía en su uso crítico y revolucionario es filosofía dialéctica materialista.

La complejidad de los fundamentos materiales de la historia obliga a penetrar el entramado de relaciones económicas y, particularmente, en lo específico del modo capitalista de producción. La matriz de comprensibilidad de la dinámica histórica dialéctica y material reside en el análisis del capitalismo, cuyas tempranas contradicciones reflejaban la necesidad de un cambio revolucionario que curara la endemia de miseria y deshumanización que causaba, tanto en los centros avanzados (Inglaterra) como en las periferias (Rusia, colonias asiáticas). Se afirmaba arriba una dialéctica progresiva de corte hegeliano que resultaba cerrada y, por tanto, ideológica, dado que no permitía penetrar las causas materiales y gestar otro tipo de relaciones. Jameson (1996) refiere que en Marx se manifiesta una segunda acepción del pensar dialéctico: "un tipo de pensamiento que pueda captar, en un solo concepto y sin que un juicio atenúe la fuerza del otro, los rasgos manifiestamente funestos del capitalismo junto a su dinamismo extraordinario y liberador” (p. 65).

La experiencia del análisis capitalista proyecta unas constantes interpretativas. En la Ideología alemana Marx define qué sería la historia tomada desde la consideración materialista: "La suma de las fuerzas productivas accesibles al hombre condiciona el estado social y que por tanto, la 'historia de la humanidad' debe estudiarse y elaborarse siempre en conexión con la historia de la industria y del intercambio" (1974, p. 28).

La historia se funda en las relaciones productivas que articulan a los hombres, las clases sociales en pugna y las maneras de generar riquezas, de generar el ámbito material de la vida humana. Tal historia del cambio social exige, se insiste, un esfuerzo investigativo; supone una penetración en los complejos fenómenos económico-sociales; es una construcción de conocimiento que identifica procesos, continuidades y rupturas, y no una mera actividad proselitista. Para Pacheco (1983):

El materialismo histórico es una ciencia filosófica de la historia que estudia la sociedad y su devenir como una realidad total y las leyes, que en consecuencia rigen su desarrollo [...] la sociedad aparece explicada como un todo que puede ser 
conocido en su movimiento, y por lo tanto en sus cambios y dirección de acuerdo a unas leyes que estarán develando el sentido de la historia. (p. 36)

El materialismo histórico es un ejercicio científico que requiere de un método investigativo, de unos criterios interpretativos de su objeto que es la dinámica histórica de las sociedades humanas. Como ciencia situada, Marx genera saber dialéctico material en el estudio del capitalismo. Y desde allí, "la investigación debe apropiarse pormenorizadamente de su objeto, analizar sus distintas forma de desarrollo y rastrear su nexo interno. Tan solo después de consumada esa labor, puede exponer adecuadamente el movimiento real” (Marx, 2008, p. 19). En su obra científica, en su estudio económico-político, Marx mostrará su concepto de historia imbricada en su proceder investigativo. Pacheco (1983) analiza:

El Capital, no es solo el análisis de la sociedad capitalista, que tiene innegables méritos de diagnóstico, sino que también es el desarrollo mismo de la teoría y la concepción de la historia, que se expresa a través de un ejemplo concreto, el Modo de Producción Capitalista. (p. 39)

Las regularidades del conocimiento se expresan en las leyes científicas. Las leyes identifican los rasgos generales de la conducta de los fenómenos interconectados alrededor de un objeto estudiado. Los nexos causales de las leyes científicas naturales son necesarios, irrestrictos. Pero el objeto social, humano, práctico, complejo e histórico del materialismo marxista no puede asimilarse idénticamente a las leyes físicas, biológicas, en su fría y aparente neutralidad objetivista. Labrousse (1969) explica:

Lo que caracteriza a la ley en ciencias humanas es precisamente su carácter de pluralidad. La ley no es una necesidad, es una probabilidad "mayoritaria”, y a veces de un grado bastante bajo. La ley no permite tanto prever cuanto apostar. (p. 98)

Con el planteamiento marxista, el oficio de la investigación científica va acercándose a una percepción de la realidad, un horizonte de comprensión dialéctico, que siendo materialista no se estatiza en las conceptualizaciones positivistas, sino que más bien ofrece una alternativa de producción cualitativa del conocimiento. La epistemología marxista conoce de la irregularidad del movimiento de la historia y de las sociedades. Aunque tiene su norte puesto en la revolución agenciada por las contradicciones destructivas del capitalismo, no se autoerige como la profecía inevitable 
que en algunas latitudes significó la intolerancia y el totalitarismo, pretendiendo así tomar el lugar de las antiguas estructuras irracionales de opresión.

De cara a las múltiples articulaciones de los infinitos elementos que estructuran la realidad, la totalidad concreta, se realiza la abstracción y el análisis reductivo propio de la ciencia y, según Bruno (2011), antes que alejarse de lo más vital y dinámico se consideran:

Los elementos como parte de un todo que simultáneamente condiciona y es condicionado por estos elementos. Al comprender la totalidad de esta manera la dialéctica recupera la peculiaridad cualitativa de los fenómenos complejos analizados. Y estas totalidades, estos fenómenos complejos, son, en este sentido dialéctico, ante todo los individuos vivientes, las particulares formaciones históricas, los presentes históricos localmente delimitados. (p. 80)

La ciencia, que es la dialéctica material de la historia, necesita de una independencia, de una autonomía respecto a su propia base material, a su propio contexto. No puede estar sometida a los dictámenes del consumismo capitalista, no puede ser la simple creadora de mercancías para uso e intercambio con perpetuo enriquecimiento de los propietarios de los medios de producción. La ciencia revolucionaria se realiza críticamente y se afirma también como motor de la historia. La ciencia genera saberes que son universalizables, pero que se tiñen de un interés particularmente emancipador. El uso de la ciencia hace que esta comparta condiciones de mantenimiento del capitalismo, o que, por el contrario, proponga incisividades que transformen lo caduco y contradictorio del capitalismo. Pacheco (1983), retomando elaboraciones de Althusser (1975), sintetiza:

La autonomía del pensamiento científico, en cuanto a los descubrimientos que aporta parece ser definitiva del sistema en que opera. Si bien hay una evidente relación con la situación histórica en que la ciencia se desarrolla, el aporte de descubrimiento se universaliza superando el contexto en que se genera. El descubrimiento así mirado, causa indesmentible de transformaciones materiales e ideológicas reclama para la ciencia una significación de motor de la historia, de promotor del cambio, que no está dependiendo del modo de producción de bienes materiales, aunque sí del progreso de éste. [...] No hay desde la ciencia un descubrimiento socialista o capitalista, si bien puede haber una utilización distinta. (pp. 42-43) 


\section{Unidad de teoría y praxis, ciencia y revolución}

En el pensamiento marxista, conocer deviene como acción indispensable para la transformación del hombre y la naturaleza. Conocer adquiere carácter crítico y revolucionario, cuando se conduce el sujeto a la toma de partido por una forma de situarse ante el horizonte político. Conoce para develar ideologías y buscar la emancipación del proletariado; o conoce para legitimar un orden explotador e injusto, que pretende perpetuar el dominio del burgués en la estructura cosificante del capitalismo. La conciencia de clase agencia la destrucción de lo ideológico en su acontecer prácticorevolucionario. Marx (1974), nuevamente en La ideología alemana, coherente con su interés emancipatorio, sentenciará:

Todas las formas y todos los productos de la conciencia no pueden ser destruidos por obra de la crítica espiritual, mediante la reducción a la "autoconciencia" o la transformación de "fantasmas”, “espectros”, "visiones”, etc., sino que solo pueden disolverse por el derrocamiento práctico de las relaciones sociales reales, de las que emanan estas quimeras idealistas; de que la fuerza propulsora de la historia, incluso la de la religión, la filosofía, y toda teoría, no es la crítica, sino la revolución. (p. 39)

Marx, desde sus tempranas formulaciones comunistas, en su labor intelectual y proselitista, quería socavar los cimientos del capitalismo en orden a un programa político revolucionario: el comunismo. En la número 11 de las Tesis sobre Feuerbach increpa: "Los filósofos han intentado hasta ahora comprender el mundo, de lo que se trata es de cambiarlo" (1974, p. 10). Coherente con su práctica investigativa, luego de una lucha frontal contra todos los géneros del idealismo que se alimentaban de la putrefacción del Espíritu Absoluto, Marx dedicaría sus investigaciones a fundamentar una ciencia revolucionaria, una crítica de la economía política del capitalismo, desde la cual examinaría el modo de producción capitalista para combatirlo revolucionariamente. El saber se formaba parte de una conciencia no subjetivista o íntima; el saber revolucionario asomaba al pensar y actuar de la clase proletaria. El historiador E. H. Carr (1970), reseñando al Marx de 30 años que proclama con Engels y la liga de comunistas el Manifiesto del partido comunista, precisa ese entronque teórico-práctico, prospectador y anticipatorio, que se volverá misión del marxismo comprendido como proyecto de acción transformadora de la historia: 
Para sucesivas generaciones de marxistas el Manifiesto no fue un alegato para la revolución — que no era necesario—, sino una predicción sobre la manera en que la revolución inevitablemente se produciría, junto con una prescripción sobre la acción adecuada de los revolucionarios para hacerla triunfar. (p. 26)

La unidad de teoría y praxis, ciencia y acción, comprensión y decisión, esos pares de producción del ser humano como entidad histórica y social, son efectuados y legitimados en el campo de la realidad concreta. La materialidad productiva, socialy espiritual se beneficia de la acción del pensamiento revolucionario. La praxis nacida de una teoría responsable y comprometida es la que agencia la liberación. Pensar en clave marxista es comprender profunda, revolucionaria y militantemente la realidad, es conceptualizar para existir y progresar políticamente como clase.

En Marx no se puede afirmar la unilateralidad de una visión del materialismo dialéctico reductor de la realidad a lo meramente físico-biológico y positivo. La dialéctica hegeliana expuso las manifestaciones de la historia humana en su comprensibilidad conceptual. Ciertos marxistas habían deformado el poder comprensivo-revolucionario de Marx, de suerte que "a pesar de su apego ortodoxo a la letra de la teoría marxista, no habían podido conservar el carácter revolucionario de esta” (Korsch, 1971, p. 34). La lucha contra el pensamiento ideológico nacido del modo capitalista no puede caer en extremos absurdos como el considerar que cambiando ideas se cambiarán prácticas, o que cambiando revolucionariamente la base material, las emanaciones conceptuales, ideológicas, desaparecerán como el humo al apagarse la llama. Kosík (1984) afirma: "La dialéctica no es el método de la reducción, sino el método de la reproducción espiritual e intelectual de la realidad, el método del desarrollo, o explicación de los fenómenos sociales partiendo de la actividad práctica objetiva del hombre histórico" (p. 52). La dialéctica se actúa al comprenderse la totalidad real al mismo tiempo que se revoluciona su estructura material, socioeconómica.

La teoría sería entonces dialéctica que se asocia a las formaciones culturales, conceptuales, intelectuales, articuladas a las rupturas, los cambios, las transformaciones que sufren las sociedades desde sus cimientos materiales y productivos, en un punto específico del devenir histórico. Así, la función fundamental y el carácter principal de la dialéctica operante en lo material productivo se hallan bien perfilados por Marx en El capital (2008): “concibe toda forma desarrollada en el fluir de su movimiento, y por tanto sin perder de vista su lado perecedero; porque nada la hace retroceder y es, por esencia, crítica y revolucionaria” (p. 20). 
Los esquemas de pensamiento conscientemente construidos para acceder a la totalidad guardan su raíz práctico-productiva: son también consecuencias productivas, son parte de la instrumentación del trabajo humano, una mediación transformadora de la realidad.

Teoría no son ideas vacías, especulaciones inútiles, conceptos tan universales y abstractos, tan evasivos y ajenos a la cotidianidad que son imposibles de vivenciar. La teoría es la producción humana que surgida de las crisis de la concretez vuelve a la realidad e ilumina el campo de la acción para poder transformarla. Althusser (1975), estudiando las peculiaridades del proceso de conocimiento marxista desde el prólogo de la Contribución al estudio de la economía política, enunciará esta definición imbricada en la consideración de los procesos de producción de conocimiento, afirmando:

Me he inspirado en la letra misma de Marx, quien emplea varias veces el concepto de "producción de conocimientos", para enunciar mi tesis central: la idea de conocimiento como producción. [...] Que tiene que ver a la vez con el trabajo, con la práctica y con la exhibición de lo verdadero [...] para llegar a la distinción de tres generalidades, la primera de las cuales jugaba el papel de materia prima teórica, la segunda el de los instrumentos de trabajo teórico y la tercera el del concreto-depensamiento, o conocimiento. (p. 25)

Teoría es reflexión sobre la realidad que permite cambiar esa realidad. Es conceptualización de las regularidades esenciales de la realidad concreta que se verifica como válida desde su potencial transformador, desde su eficacia en la conquista de una sociedad igualitaria. Por eso cuando se asume la fundamentación materialista de la dialéctica de la historia con todo su poder de contradicción, la burguesía se aterra, pues "en la intelección positiva de lo existente incluye también, al propio tiempo, la inteligencia de su negación, de su necesaria ruina” (Marx, 2008, p. 20).

Así pues, no podemos entender la teoría si no surge del interior de la totalidad real y se proyecta consecuentemente en praxis. Tampoco se acepta la praxis si no comprende la complejidad del mundo material desentrañando sus nexos causales en una intelección compleja que regule y oriente su desarrollo. Se concibe lo teórico como un gran esfuerzo de comprensión de la totalidad concreta que ha hecho posible conectar los fenómenos con su esencia material. No sería justo con Marx disolver la economía política y la ciencia materialista dialéctica de la historia en unas cuantas consignas pseudorrevolucionarias que se aplican a todo y por todo, sin un acercamiento reflexivo, serio y ponderado a la complejidad material y social. Hacer ciencia 
y hacer filosofía significa una comprensión revolucionaria que alimenta el cambio histórico; ciencia y filosofía develan los substratos ideológicos y dialécticamente serán impulsoras de saberes rebeldes y agenciadores de nuevas relaciones sociales. El conocimiento, la ciencia y la filosofía marxista, Korsch (1971) los definió, siguiendo las propuestas de Marx, como socialismo científico:

Nada más ajeno a Marx que la adhesión a una investigación puramente científica, sin supuestos ni carácter de clases [...] El socialismo científico es la expresión teórica de un proceso revolucionario que llegará a su fin con la abolición total de esas filosofías y ciencias burguesas al mismo tiempo que con la supresión de las condiciones materiales que han encontrado su expresión ideológica en estas filosofías y ciencias. (p. 36)

La teoría y la praxis constituyen la gran unidad del conocimiento humano. Si esta unidad se rompe acentuando una de sus partes, caeríamos en el teoricismo engañador -ideologizante, metafísico - o en el activismo estéril, agotador, sin sentido ni rumbo, que sirve a los intereses del autoritarismo o el populismo. El pensar solo es tal cuando también es conciencia política, es práctica de efectiva participación política. Ese pensar es, además de riguroso, sistemático, pertinente, profundo y analítico, revolucionario: pretende no perpetuar una sociedad de clases, injusta, sino crear una sociedad igualitaria, que ofrezca las mismas oportunidades y derechos para todos. Nuevamente con Althusser (1975) se puede afirmar que Marx concibió una comprensión práctico-teórica, manifestando un pensamiento insólito y revolucionario:

Insólito porque Marx había fundado, en un trabajo de elaboración conceptual, que comienza con "La ideología alemana" y culmina con "El capital”, lo que en una primera aproximación se podría llamar la ciencia de la historia. Revolucionario pues [...] provocaba un trastorno en la filosofía: no solamente obligándola a refundir sus categorías para adecuarlas a la ciencia nueva y a sus efectos, sino sobre todo dándole, mediante el conocimiento de su relación real con la lucha de clases, la manera de asumir y transformar su práctica. (pp. 8-12)

¿En dónde queda la filosofía? Si congelamos el pensamiento marxista en la definición de una ciencia positivista de la revolución que disuelve lo ideológico, se cae en el reduccionismo de una definición simplista: cuando no haya capitalismo, su emanación ideológica, la filosofía, desaparecerá. Marx, muy dialécticamente, ataca con el poder negativo de la crítica ese lado perverso de la filosofía idealista. Tal enunciación ideológica de las filosofías idealistas es una realidad, arrastra hechos y decisiones 
en la existencia, en los intercambios de cada día. Lo filosófico es real, y por ello su lucha demanda no solo el trabajo cognitivo-analítico, sino también la realización de su opuesto práctico. Hay que hacer la revolución que suprime las causas materiales originantes de ese espectro ideológico señalado como único, verdadero e incontrovertible. Es indispensable hacer surgir las condiciones sociales concretas opuestas a esas realidades ideológicas.

Korsch (1971) señala entonces que

el materialismo dialéctico de Marx y Engels [...] por su carácter teórico puede conceptuarse con toda justicia como filosofía, esto es, como una filosofía revolucionaria que se plantea la tarea, en cuanto filosofía, de llevar adelante realmente la lucha revolucionaria que se desarrolla simultáneamente en todas las esferas de la realidad social. (pp. 40-41)

En otras palabras, se debe realizar la filosofía como concreción de un estado de cosas reales muy diferente al pregonado y enaltecido por las fundamentaciones ideológicas. Y llegando a un nivel mayor y más auténtico de realidad, esa filosofía crítica desaparece, hasta que la misma dinámica de la realidad exija ejercer nuevamente la crítica para una nueva transformación orientada a la emancipación. Como se ha afirmado antes, la dialéctica que une teoría y praxis no conoce un momento real definitivo, absoluto e incuestionable. Siempre lo dialéctico impulsará novedad de hacer y de pensar. Dogmatizar sería destruir la vida dialéctica de la historia. Así, hacer filosofía - comprender filosóficamente, críticamente, proletariamente, revolucionariamente- es superar la filosofía. Marx (1968[1844]) dirá en la introducción a la Crítica del derecho de Hegel: "Vosotros no podéis suprimir la filosofía sin realizarla” (p. 14).

\section{Conclusiones}

Pese a las críticas contra el posible historicismo marxista señalado ácidamente por pensadores como Popper, pese a la caída del muro de Berlín y la reunificación alemana, pese a la dejación de armas de los movimientos guerrilleros colombianos, pese al auge comercial de China, el marxismo y su legado no puede ser objeto de un ingenuo olvido. El pensamiento marxista decantado de posibles malversaciones, purificado por el fuego inextinguible de los movimientos sociales libertarios, ajeno a dogmas y 
absolutizaciones partidistas, tiene aún mucho que decir al pensamiento social y a los caminos sapientes de transformación histórica.

En la reflexión de la Escuela de Fráncfort la continuación del ejercicio rebelde, desideologizante, ético y político de izquierda, reconstruido de la tradición marxista, ha dado como resultado en Habermas la operación de un pensamiento epistemológico, cuyo dinamismo dialéctico reflexiona como crítica de la ideología. Con Marx, Habermas redimensiona la misión de la filosofía y de la teoría de la sociedad, al orientarla hacia el examen de los productos de la ciencia, de suerte que "La filosofía es conservada en la ciencia como crítica [...] La herencia de la filosofía se traslada más bien a la actitud de la crítica ideológica, actitud que determina el método del mismo análisis científico" (Habermas, 1982[1968], p. 73).

Derrida, en su original y muy polémico Espectros de Marx (1998), ve en Marx no una entidad única y objetiva, sino muchas versiones, muchos fantasmas, muchos espectros que como el comunismo han recorrido lugares y épocas, hasta llegar elocuentes a nuestro tiempo, un tanto desquiciado. Así declara la vigencia del análisis marxista:

Será siempre un fallo no leer y releer y discutir a Marx. [...] Será cada vez más un fallo, una falta contra la responsabilidad teórica, filosófica, política. Desde el momento en que la máquina de dogmas y los aparatos ideológicos "marxistas" (Estados, partidos, células, sindicatos y otros lugares de producción doctrinal) están en trance de desaparición, ya no tenemos excusa, solamente coartadas, para desentendernos de esta responsabilidad. No habrá porvenir sin ello. No sin Marx. No hay porvenir sin Marx. Sin la memoria y sin la herencia de Marx: en todo caso de un cierto Marx: de su genio, de al menos uno de sus espíritus. (p. 27)

El legado marxista, su validez a doscientos años del natalicio del pensador, radica en la agudeza y la flexibilidad dinámica de sus estructuras de comprensión. Marx sabía de la relatividad de todo planteamiento: la base factual y epocal del pensamiento se multiplica y difumina en el complejo tejido de hechos económicos, sociales, políticos, culturales. Congelar y anquilosar esas estructuras comprensivas en lemas de campaña electoral o consignas para gritar en manifestación pública es desconocer y contravenir el horizonte crítico de Marx. Marx conocía de la brevedad y fragilidad de los argumentos atados al tiempo; no podía considerarse demasiado marxista. El mordiente del pensamiento dialéctico hace posible clarificar las relaciones sociales y las acciones revolucionarias, así como los compromisos a favor o en contra del capital. No se puede descontextuar a Marx, volverlo el Moisés del comunismo, ni exigirle 
productos y elaboraciones que no tenía por qué desarrollar con las limitaciones de unas ciencias sociales demasiado jóvenes y librescas (Schumpeter, 2003). Wallerstein (1988) indica la trascendencia de Marx para las ciencias sociales:

Fue una figura monumental en la historia intelectual y política moderna. Nos ha dejado un gran legado, conceptualmente rico y moralmente inspirador. Sin embargo, deberíamos tomar en serio lo que dijo de que no era marxista, y no desecharlo como una ocurrencia. Marx sabía, cosa que muchos de los que se dicen discípulos suyos no saben, que era un hombre del siglo xix cuya visión estaba inevitablemente limitada por esa realidad social. Sabía, cosa que muchos no saben, que una formulación teórica solo es comprensible y utilizable en relación con la formulación alternativa a la que aquélla ataca explícita o implícitamente, y que es totalmente irrelevante para formulaciones de otros problemas basados en otras premisas. (p. viII)

Marx renegó de la filosofía de talante idealista, pues la juzgaba como una disciplina defensora de los intereses de la clase dominante, como ideología que justificaba el sistema de opresión, que en últimas constituía el arma discursiva de las élites y el Estado, para perpetuar las maquinaciones de un sistema explotador. Marx investigó acerca de la realidad económica y su conexión con la organización política. Marx enaltecería el poder crítico de la filosofía bajo el direccionamiento de la práctica histórica, bajo la realización de lo sociopolítico, depurando la funcionalidad de la razón como instrumento de crítica revolucionaria efectiva. Desde el punto de vista político, Marx ha contribuido al conocimiento humano, prospectando un tipo de sociedad y de relación productivo-política que ha iluminado los posteriores desarrollos económicos y políticos.

En Marx conocer es hacer, lo epistémico se valida en lo ético-político, la unidad de teoría y praxis es también la acción real que busca el bienestar libertario del cambio revolucionario. El comunismo marxista brilla como un deber ser al que debieran llegar todos los hombres y todas las naciones de la tierra. El soporte fundamental es el económico y junto a este, el carácter de proceso de conciencia que legitima una formación política opuesta a los múltiples mecanismos de ideologización del sistema capitalista. Cortina y Martínez (2001), en esta línea de comprensión, afirman:

Marx no intentó hacer una ética y, sin embargo, el mejor legado de la filosofía marxista tal vez consista precisamente en constituir una provocación moral en pro de 
la justicia y de la construcción de una utopía en la que todos los seres humanos lleguen a sentirse libres de dominación. (pp. 81-82)

La contribución de Marx que más golpea la conciencia de Occidente se realiza en el campo de la historia. Sin negar la cuna idealista hegeliana, Marx consideraba los hechos históricos positivos, concretos, desde una dinámica globalizante, capaz de penetrar en la superficie de las irregularidades hasta abarcar la lógica grandiosa de la historia. Con Marx se ha establecido que la historia no es la fría recopilación de datos o la enumeración de hazañas o gestas heroicas, tan características del talante romántico, burgués y nacionalista. Toda labor histórica se sitúa en una óptica y una opción política que permite la identificación de las transformaciones sociales. Quien forja la historia es el ser humano como clase social, como constitutivo de un engranaje económico-político que entra en crisis y cambia. No se concibe el relato histórico sin la definición de una postura política. En ello no ponía meramente pasión, ni tampoco un simple y sutil afecto por el análisis, ambas cosas se daban simultáneamente - pasión política y análisis factual—, llegando así a estar muy por encima de cualquier sociólogo e historiador de la época (Carr, 1970). El talante crítico del ejercicio social del conocer constituye entonces la fuerza para transformar la realidad y gestar el mundo en donde todos tienen cabida para su plenificación en la libertad.

Marx penetró en el corazón mismo del sistema económico en su obra El capital. Para Marx, el proceso económico no se apoya meramente en factores externos en la explicación del paso de un sistema económico a otro. Concibe la evolución económica como un proceso diferenciado en sí mismo y engendrado por el propio sistema económico. Mostró con una sorprendente capacidad analítica cómo el proceso económico, al cambiar por virtud de su propia lógica inherente, transforma incesantemente la estructura social, esto es, la sociedad en su conjunto. "The forms of production themselves have a logic of their own; that is to say, they change according to necessities inherent in them so as to produce their successors merely by their own working”2 (Schumpeter, 2003, p. 13).

Para Marx, las condiciones productivas o formas de producción constituyen el determinante fundamental de las estructuras sociales que, a su vez, engendran las actitudes, las acciones y las civilizaciones. Consecuentemente, las formas de producción se transforman por necesidades inherentes a ellas mismas, de tal suerte que, en

2 "Las formas de producción tienen una lógica propia, es decir, cambian de acuerdo con las necesidades inherentes a ellas mismas transformándose exclusivamente por su propia evolución”. La traducción es mía. 
virtud de su propio desarrollo, terminan engendrando las formas productivas que han de sucederles. Resulta absolutamente necio el planteamiento político que no busque el fortalecimiento de una base productiva por la cual el trabajo sea una realidad de todos en una estructura social igualitaria y equitativa.

Quebrar una economía y empobrecer aún más a los ya deprimidos es muy poco marxista. Alimentar los hábitos de corrupción y enriquecer a unos cuantos, así sean “paladines de la revolución”, es absurdo. Masacrar trabajadores, campesinos, estudiantes, artistas, religiosos, ciudadanos de la oposición, es una aberración que no se puede cometer en nombre del poder del pueblo. Blindarse contra cualquier crítica silenciando a los medios y a los contradictores es matar la cuna de pensamiento rebelde que funda al materialismo histórico.

Paradójicamente, la evolución económica tendría la fuerza suficiente para que no se necesite el concurso de la violencia, que por desgracia ha oficiado malamente de partera de las revoluciones. La ciencia económica, la ciencia histórica y la ciencia política siempre volverán sobre los pasos de Marx para criticar y desideologizar, para proponer mayores progresos del hombre social. De hecho, la ciencia históricopolítica de la actualidad debe su auge a la reconstrucción — con los elementos de la econometría, las investigaciones macro-y microeconómicas, así como los aportes de la antropología - del sistema teórico-interpretativo denominado "materialismo histórico".

\section{Sobre el autor}

Jaime Ricardo Reyes Calderón. (Cúcuta, 1964). Doctor en Educación por la UPEL (Venezuela, 2017). Actualmente es coordinador del Colegio Oficial Santo Ángel de Cúcuta y miembro de número de la Academia de Historia de Norte de Santander. Es licenciado en Filosofía por la Pontificia Universidad Javeriana de Bogotá (1987), donde también realizó estudios de Teología (1987-1990). Especialista en Literatura por la Universidad del Quindío (1996) y en Orientación y Desarrollo Humano por la Universidad El Bosque (1998) y magíster en Educación por la Universidad Santo Tomás de Bogotá (2010). Además realizó estudios de Historia en la Pontificia Universidad Javeriana de Bogotá (2000). Ha publicado los libros: Teoría y didáctica del género terror (2007), Teoría y didáctica de los géneros aventura y policíaco (2003), Teoría y didáctica del género ciencia ficción (3. ${ }^{\mathrm{a}}$ edición, 2012), en la Cooperativa Editorial Magisterio, de Bogotá, y los libros de filosofía Hombre: ser y conocer (2010) y Hombre: actuar $y$ crear (2010). Su tesis de maestría se publicó en el libro escrito en colaboración La educación moral, camino de humanización (2014), de la Universidad Santo Tomás, Colombia. Ha publicado artículos de investigación en reconocidas revistas académicas como: Kipus. Revista Andina de Letras y Estudios Culturales (Ecuador), Letras (Venezuela), Albertus Magnus (Colombia), Academia \& Derecho (Colombia), Ingenio Ufpso (Colombia) y en Káñina (Costa Rica). 


\section{Referencias}

Althusser, L. (1975). ¿Es fácil ser marxista en filosofía? Ideas y Valores, (42-45), 5-38.

Botero, D. (1996). El poder de la filosofía y la filosofía del poder. Bogotá: Universidad Nacional de Colombia.

Bruno, D. (2011). La dialéctica histórica de Karl Marx. Recuperado de http://bibliotecavirtual. clacso.org.ar/Argentina/iigg-uba/20120628034903/1_7.pdf

Cardozo, C. y Pérez, H. (1976). Los métodos de la historia. México: Grijalbo.

Carr, E. H. (1970). Estudios sobre la revolución. Madrid: Alianza.

Cortina, A. y Martínez, E. (2001). Ética. Madrid: Akal.

Derrida, J. (1998). Espectros de Marx. Madrid: Trotta.

Desanti, J. (1975). Materialismo y epistemología. Ideas y Valores, (42-43-44-45), 77-95.

Dunayevskaya, R. (2004). Filosofía y revolución. De Hegel a Marx y de Sartre a Mao. México: Siglo XXI.

Duque, F. (1999). La restauración. La Escuela hegeliana y sus adversarios. Madrid: Akal.

Engels, F. (2014). Anti-Düring. Madrid: Fundación Federico Engels.

Habermas, J. (1982[1968]). Conocimiento e interés. Madrid: Taurus.

Habermas, J. (2005). Facticidady validez. Madrid: Trotta.

Hegel, G. (2000[1821]). Filosofía del derecho. Madrid: Biblioteca Nueva.

Hegel, G. W. (2010[1807]). Fenomenología del Espíritu. Madrid: Abada/UAM.

Hegel, G. W. (2011[1812]). Ciencia de la lógica. Madrid: Abada/UAm.

Hegel, G. W. (2005[1830]). Enciclopedia de las ciencias filosóficas. Madrid: Alianza.

Hobsbawn, E. (1998). Historia del siglo Xx. Barcelona: Crítica.

Jameson, F. (1996). Teoría de la postmodernidad. Madrid: Trotta.

Jaramillo, R. (1998). Algunas consideraciones sobre el asunto "Marx hoy". A propósito de la recepción de su pensamiento en la desaparecida Unión Soviética. Ideasy Valores, 47(108), 39-55.

Korsch, K. (1971). Marxismo y filosofía. México: ERA.

Kosík, K. (1984). Dialéctica de lo concreto. México: Grijalbo.

Labrousse, E. (1969). Las estructurasy los hombres. Barcelona: Ariel.

Lowy, M. (1998). La dialéctica marxista del progreso en Marx. En R. Vega (Ed.), Marxy el siglo XXI. Bogotá: Antrophos. 
Marx, K. y Engels, F. (1974). Obras escogidas. Moscú: Progreso.

Marx, K. (1968[1844]). Crítica a la filosofía del derecho de Hegel. Buenos Aires: Claridad.

Marx, K. (1974a). La ideología alemana. Barcelona: Grijalbo.

Marx, K. (2008). El capital. México: Siglo XXI.

Marx, K. (2012). Escritos sobre materialismo histórico. Madrid: Alianza.

Pacheco, L. (1983). La ley histórica en Marx y el cuestionamiento del materialismo histórico. Universitas Humanistica, 20(20), 35-64.

Schumpeter, J. (2003). Ten great economists. Londres: Taylor \& Francis e-Library.

Vattimo, G. (2012). Vocación y responsabilidad del filósofo. Barcelona: Herder.

Vega, R. (2005). Teoría marxista de la historia. Recueperado de http://www.archivochile.com/ Ceme/recup_memoria/cemememo0043.pdf

Wallerstein, I. (1988). El capitalismo histórico. Madrid: Siglo XXI. 